(6) OPEN ACCESS

\title{
The effect of excise tax increases on cigarette prices in South Africa
}

\author{
Daniel J Linegar, Corne van Walbeek
}

School of Economics, University of Cape Town, Rondebosch, South Africa

\section{Correspondence to}

Professor Corne van Walbeek, School of Economics Building, University of Cape Town, Rondebosch, 7701, South Africa; cwalbeek@gmail.com

Received 25 July 2016 Revised 15 December 2016 Accepted 25 December 2016 Published Online First 24 March 2017

\section{CrossMark}

To cite: Linegar DJ, van Walbeek C. Tob Control 2018;27:65-71.

\section{ABSTRACT}

Introduction The effectiveness of excise tax increases as a tool for reducing tobacco consumption depends largely on how the tax increases impact the retail price. We estimate this relationship in South Africa for 2001-2015.

Data Statistics South Africa provided disaggregated cigarette price data, used in the calculation of the Consumers' Price Index. Data on the excise tax per cigarette were obtained from Budget Reviews prepared by the National Treasury of South Africa.

Methods Regression equations were estimated for each month. The month-on-month change in cigarette prices in February through April was regressed against March's excise tax change to estimate the pass-through coefficient. For the other 9 months, the month-onmonth change in cigarette price was regressed against monthly dummy variables to determine the size of the non-tax-related price increase in each of these months. The analysis was performed in both nominal and real (inflation-adjusted) terms.

Findings Expressed in real terms, the excise tax was undershifted. A R1.00 (one rand) increase in the excise tax is associated with an increase in the retail price of cigarettes of R0.90 in the pre-2010 period, and R0.49 in the post-2010 period. In the pre-2010 period, the tobacco industry increased the retail price of cigarettes in July/August, independent of the excise tax increase. The discretionary July/August price increases largely disappeared after 2010, primarily because the market became more competitive.

Conclusion The degree of excise tax pass-through, and the magnitude of discretionary increases in cigarette prices, is significantly determined by the competitive environment in the cigarette market.

\section{INTRODUCTION}

The effectiveness of excise tax increases as a tool for reducing tobacco use depends on how the tax increase impacts the retail price of the product. ${ }^{1}$ People change their purchasing behavior in response to retail price changes, not in response to excise tax changes. Typically, smokers have no incentive to know the tax amount on cigarettes (and probably do not know the quantum of the tax), but they are made aware of the retail price at each purchase occasion. There is consensus in the literature that, despite the addictiveness of nicotine, an increase in tobacco prices does reduce tobacco consumption. ${ }^{1}$

An excise tax increase typically increases the price of cigarettes. The magnitude of the price increase depends on the degree to which the tax increase is passed through to consumers. The degree of passthrough thus determines the effectiveness of the excise tax in reducing tobacco consumption (apart from the hypothetical cases in which demand or supply is perfectly price-inelastic). For example, a fully passed-through tax increase is more effective in reducing tobacco consumption than a tax increase partially borne by the producer. This paper considers the dynamics of cigarette excise tax passthrough in South Africa.

For many years, South Africa was regarded as a pioneer in tobacco control among low-income and middle-income countries, particularly for its use of excise taxes. ${ }^{2}$ Value-added tax (VAT) has been levied at $14 \%$ of the (ex-VAT) retail price since 1993. In 1994, excise taxes and VAT, combined, comprised $33 \%$ of the retail price of cigarettes. In that year, the government announced that it would target a total tax burden on cigarettes of $50 \%$, to be achieved within an unspecified number of years. ${ }^{3}$ In 1997, the government announced it had reached the target. ${ }^{3}$ The excise tax in South Africa is levied as a uniform specific tax. Between 1998 and 2005 the government annually adjusted the excise tax to maintain the 50\% total tax threshold. In 2006 the total tax target was increased to $52 \%$ of the recommended retail price of the most popular brand. Since 2006 the tax regime and the targeted tax percentage has remained unchanged.

British American Tobacco (BAT) is the dominant cigarette producer and distributor in South Africa. Before 2010 BAT's main competitors were other multinationals (Philip Morris International, Japan Tobacco International and Imperial Tobacco), but BAT was the unchallenged price leader. According to Euromonitor, BAT had a $91 \%$ market share in $2005^{4}$ and although its market share has decreased somewhat subsequently, it is still above $80 \% .^{5}$ BAT had much pricing power to substantially increase the net-of-tax price of cigarettes. Whereas the real (inflation-adjusted) net-of-tax price of cigarettes remained broadly constant (and even decreased slightly) between the early 1960s and early 1990s, it doubled between 1994 and 2010. This, together with a fivefold increase in the real excise tax, resulted in a near-tripling of real cigarette retail prices between 1994 and 2010. The rapid increase in cigarette prices, together with sluggish economic growth, meant that cigarettes became substantially less affordable. ${ }^{6}$ Because of these price increases and other factors, including tobacco control interventions, smoking prevalence decreased from approximately a third to less than a fifth between 1994 and 2012. ${ }^{27}$

In 2010 the South African cigarette market changed substantially. The high profits earned by BAT and other multinationals attracted many small cigarette manufacturers and distributors, 
who undermined the established firms. The new entrants were primarily competing in the low-price segment, selling at prices substantially lower than the economy brands sold by the incumbents. There was also a substantial increase in the illicit market that year. ${ }^{8}$

This paper estimates the pass-through of cigarette excise taxes before and after 2010 in South Africa. South Africa is an important example for other countries, since it was one of the first middle-income countries to use excise tax increases as a tobacco control tool. The paper adds to the literature on excise tax pass-through, ${ }^{9-15}$ but, crucially, considers a structural break in the industry's pricing reaction to excise tax increases.

\section{DATA}

This paper uses monthly cigarette price data collected by Statistics South Africa from December 2001 to December 2005 and from January 2008 to December 2015. Statistics South Africa provided us the data on request. The gap in the data is due to a change in the data capturing system at Statistics South Africa, when the price data were 'lost'. The price data are used to compile the Consumers' Price Index, and is typically collected in the first 2 weeks of each month. The Consumers' Price Index (CPI) is published around the 20th of the following month. All prices refer to packs of 20 cigarettes. Each of the 97948 observations (over 145 months) contains (1) the brand, (2) the price and (3) the geographical region of the outlet (the name of a city, town, municipality or a defined rural/urban area within a town). In the sample there are 51 different brands and 77 regions, corresponding to the sampling frame used by Statistics South Africa.

For each month, an average price was calculated across outlets for each brand-region combination, subject to there being at least three observations for that brand in that month (irrespective of region). A total of 1626 observations (1.7\%) was excluded from the analysis because they did not meet this requirement. Where a price observation deviated by more than three standard deviations or by more than $50 \%$ from the mean price for the associated brand-month combination, the observation was dropped on the grounds that it was either not representative of that brand-month combination, or an error. As a result 889 observations $(0.9 \%)$ were excluded. Month-on-month differences of these brand-region average prices were calculated for each month, which gave us a total of 32836 observations for use in the regressions. The observations used in the regressions were based on an average of 2.9 raw observations (ie, (97 948-1 626-889)/32 836).

Statistics South Africa informed the authors that the same retail outlets are surveyed from month to month. Where this was not possible (eg, an outlet closed down), they would sample a similar retail outlet from that region in order to keep the sampling frame as consistent as possible over time.

We used multiple annual Budget Reviews, prepared by the National Treasury of South Africa, to obtain the excise tax per pack of cigarettes, which is levied as a uniform specific tax. The excise tax is adjusted in late February each year. The largest nominal excise tax increase in the sample was R1.24 in 2010 (from R7.70 to R8.94), while the smallest was R0.34 in 2002 (from R3.17 to R3.51). To synchronie the tax changes with the price changes, the tax increase is reflected in March, because by the time the excise tax increase is announced, the price survey in February is already completed.

We performed the analysis in both nominal and real terms. Results are presented for both nominal and real prices since there is no a priori reason for a similar magnitude of pass through when month-to-month variations in general (all-CPI) inflation rates are corrected for. For the analysis in real terms, the effect of inflation is removed by dividing all price and tax data by the appropriate Consumers' Price Index (base December 2012). The South Africa currency is rand (R). The value of the currency fluctuated over the period of analysis, but averaged about US $\$ 0.10$ per R.

\section{METHODOLOGY}

The study aims to estimate the extent to which the cigarette retail prices change in response to an excise tax change. To maintain their per-pack profit, and holding costs constant, a R1 increase in the excise tax would force firms to increase the retail price by R1.14 (because 14\% VAT is levied on the excise tax as well). The tax increase does not obligate firms to raise prices by R1.14 immediately, or even at all. The tax increase could be passed through over several months. The degree to which the firm is able to pass through the tax increase is influenced by the degree of market competition and individual firms' discretion.

In its simplest form, one would regress the change in the average retail price of brand $i$ in region $j$ in March (ie, $\Delta \overline{P_{i j M a r c h}}=\overline{P_{i j M a r c h}}-\overline{P_{i j F e b r u a r y}}$ ) on the change in the excise tax in March (ie, $\Delta T_{\text {March }}$ ). The coefficient on $\Delta T_{\text {March }}$ indicates by how much the retail price of cigarettes increases in response to a one unit increase in the excise tax. The magnitude of this pass-through coefficient $\beta$ allows one to determine whether the tax is contemporaneously overshifted $(\beta>1.14)$, undershifted $(\beta<1.14)$ or fully passed through $(\beta=1.14)$. The split occurs at $\beta=1.14$, rather than at $\beta=1$, because the excise tax is subject to VAT (14\%).

Tobacco companies could pre-emptively raise the price of cigarettes (ie, before the tax increase is announced), or delay the price increase for competitive or other reasons. We assume that, other than the contemporaneous effect, the tax increase influences the price 1 month on either side of March. The decision to use this time horizon was driven by (1) a preliminary empirical analysis of the data at hand and (2) a literature (not limited to only tobacco) that indicates that the full impact of a tax increase on the price typically happens within 3 months. ${ }^{16-18}$

For each of the monthly price changes in February, March and April, we estimate the following regression equation:

$$
\Delta \overline{P_{i j y t}}=\beta_{p t} \cdot \Delta T_{y M a r c h}+\varepsilon_{y t}
$$

where $t$ denotes the month (February, March and April for the pre-emptive, contemporaneous and delayed price changes, respectively), $y$ the year, $p$ the period (pre-2010 or post-2010) and $\varepsilon_{y t}$ the idiosyncratic error term.

For the other 9 months of the year, we assume that any price changes are discretionary, determined by the strategic prerogatives of the tobacco industry. For each of these months, we estimate the following regression equation:

$$
\Delta \overline{P_{i j y t}}=\delta_{p t} \cdot(\text { Month } t)+\varepsilon_{y t}
$$

where $t$ denotes the month (May through January), is a dummy variable $=1$ if the month is $t$ and $=0$ otherwise, $y$ denotes the year, $p$ denotes the period (pre-2010 or post-2010) and $\varepsilon_{y t}$ is an idiosyncratic error term.

The $\beta$ coefficients in equation (1) are pass-through coefficients, while the $\delta$ coefficients in equation (2) show the 
month-on-month price increase, on average, in the month to which it refers.

All regressions are estimated by weighted least squares (WLS), with heteroskedasticity-robust standard errors, using Stata version 12. We use WLS, rather than ordinary least squares, to give appropriately more weight in our regressions to a brand-region average price that is comprised of a larger number of individual price observations than other brand-region average prices. We present the results first in nominal terms and then in real terms.

The model is parsimonious, in that the pass-through coefficients are based solely on the tax changes and the model does not control for an underlying trend in the price, or for changes in the costs of production. Not controlling for changes in the cost of production could bias the pass-through coefficients. In particular, if the price increase in February, March and April is the result of both excise tax and production cost increases, the pass-through coefficient will be biased upwards, because the impact of the cost increase on the price increase will be wrongly attributed to the tax change. Given South Africa's moderately inflationary environment (averaging 5.8\% between December 2001 and December 2015), it seems likely that nominal per-cigarette cost of production has increased. As such, the pass-through coefficients obtained in this specification are probably biased upwards and should therefore be considered upper limits.

In the specification in real terms, the pass-through coefficients will be biased upwards only if the real costs of production were increasing (ie, the nominal costs of producing cigarettes were increasing more rapidly than the inflation rate). If the real costs of production were decreasing, the pass-through coefficients would be biased downwards. The fact that we cannot control for changes in the cost of production, is a drawback of this study. The tobacco industry is not obliged to publish such costs, which are regarded as confidential. The tobacco industry certainly has no incentive to provide them to the authors. Some published studies, especially those that use industry data, control for costs, ${ }^{14-1619-21}$ but others do not. ${ }^{22-26}$

The study assumes that wholesale and retail margins have remained constant over time. While we do not have data to test this assumption, it seems unlikely that the margins have increased over time because they are currently very low (typically around $10 \%)$. Competition between retailers is fierce, putting pressure on retail margins. Competition between the large cigarette manufacturers is limited, allowing them to push up prices. We are confident that retail price increases are influenced more by changes in the ex-factory price charged by cigarette manufacturers, than by wholesalers' or retailers' margins.

\section{RESULTS}

\section{Graphical analysis}

Figure 1 presents the monthly weighted average nominal price of a pack of cigarettes for the period December 2001 to December 2015, barring a 2-year gap in 2006 and 2007, and the nominal excise tax amount per pack over the same period. The increase in the nominal price of cigarettes is near-monotone, but there are definite steps around March and, less-pronounced, around July and August. The March price increase corresponds to the excise tax increase, but the price increase in July/August seems to be discretionary.

Effective excise tax policy considers changes in the real excise tax, rather than changes in the nominal excise tax..$^{27}$ In figure 2 we present the average price and excise tax on cigarettes in real terms. The nominal excise tax increases monotonically. In contrast, the real excise tax has a jagged shape; it increases each March but slowly erodes over the course of the year under the influence of inflation.

Figure 2 appears to indicate a structural break in cigarette prices and taxes in April 2010. Between December 2001 and April 2010 the real price and the real excise tax on cigarettes

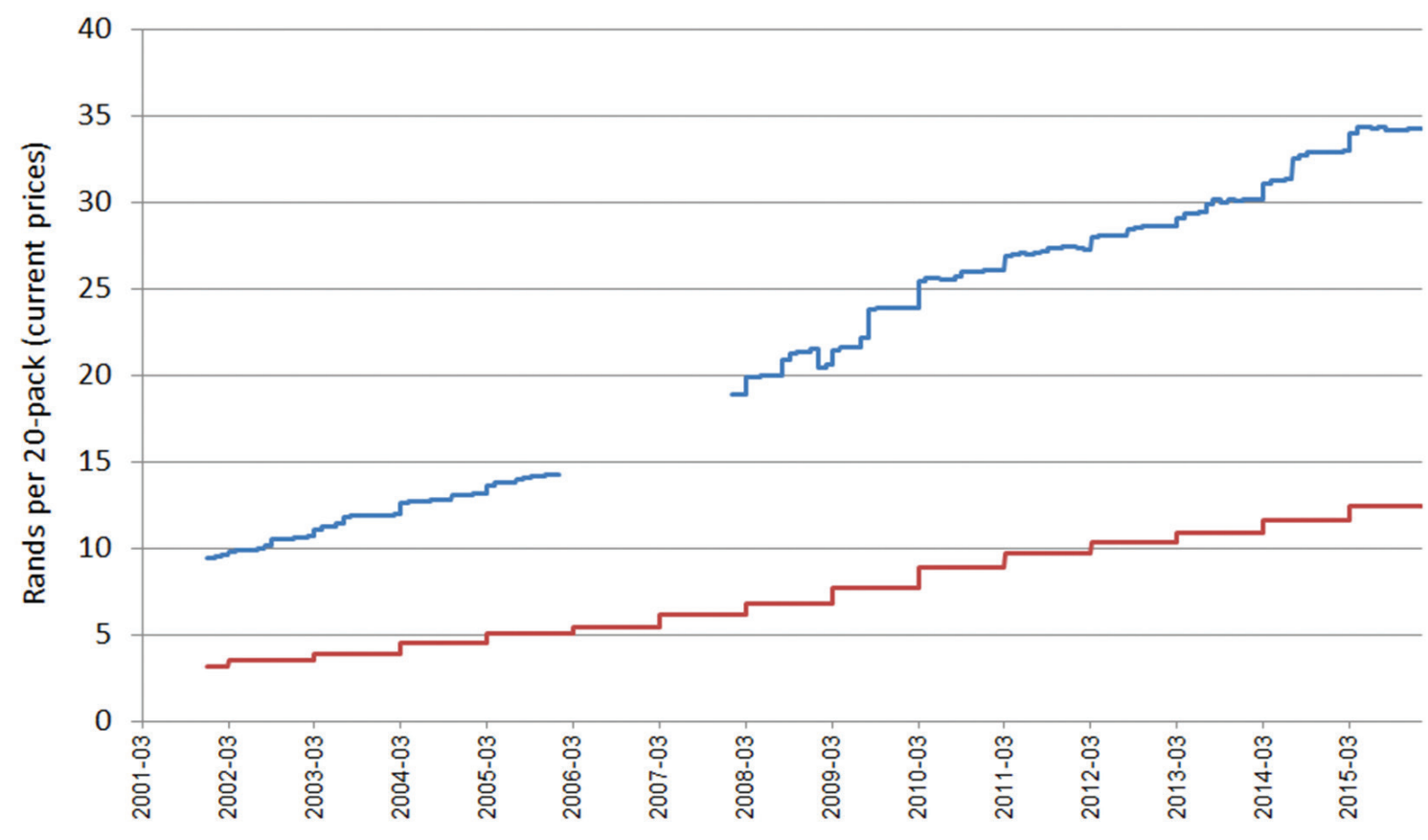

—Nominal retail price (All brands) —Nominal excise tax

Figure 1 Nominal average retail price and excise tax on cigarettes, South Africa, 2001-2015. 


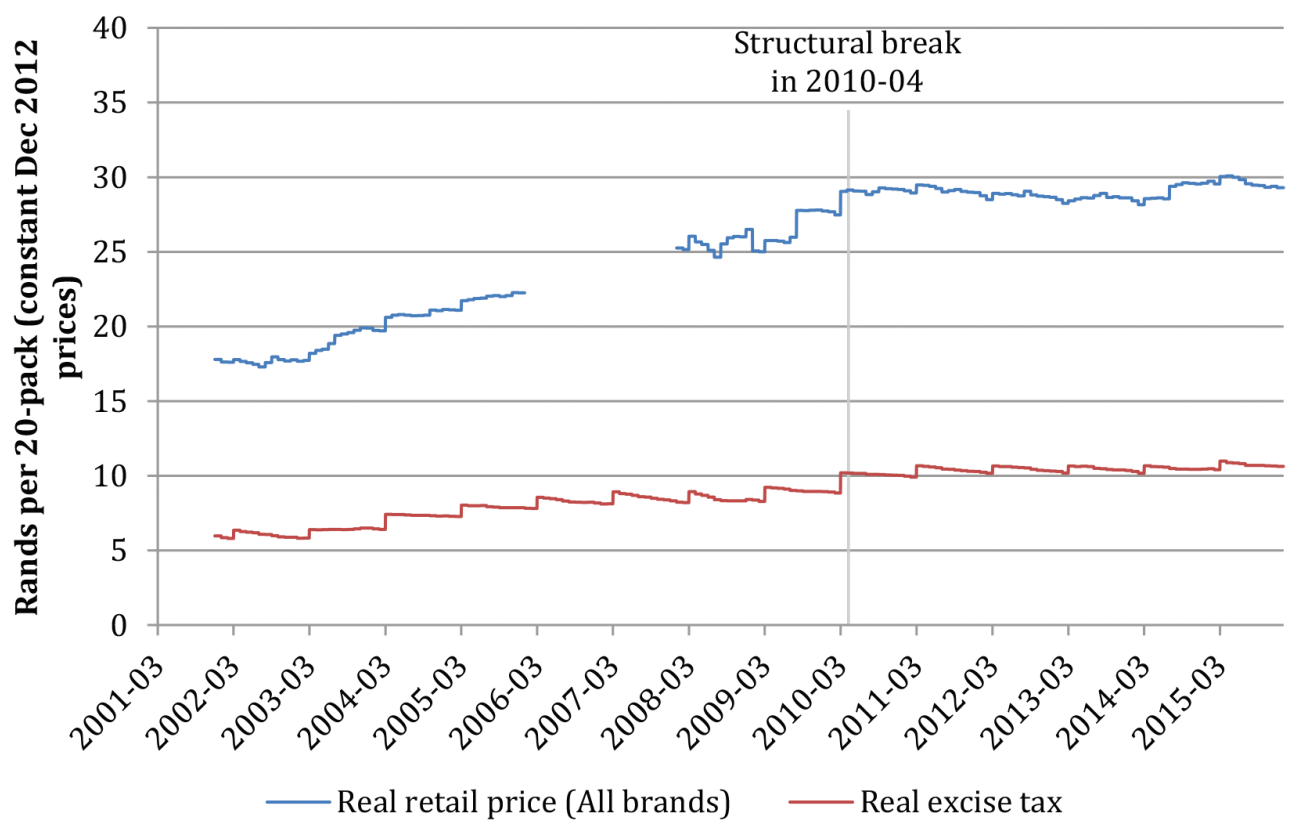

Figure 2 Real average retail price and excise tax on cigarettes, South Africa, 2001-2015.

increased by $64 \%$ and $71 \%$, respectively. In contrast, between April 2010 and December 2015, the real price and real excise tax remained broadly constant. We performed Chow tests to test formally for a structural break in cigarette pricing in April 2010. If there was no structural break, each population passthrough coefficient and monthly effect would be the same after April 2010 as it was before April 2010. We find strong evidence that this is not the case. In particular, the contemporaneous passthrough estimates differ significantly before and after April 2010 $(\mathrm{p}<0.001$ for the Chow tests on nominal and real data). Furthermore, the 9-monthly effects (May through December) differ significantly before and after April 2010 ( $p<0.05$ for all months in both nominal and real terms). These results give strong statistical support to our claim that there was a structural break in cigarette pricing in April 2010. Within this context, the empirical work considers two periods: December 2001 to March 2010 and April 2010 to December 2015.

\section{Estimating the pass-through coefficients}

Analysis in nominal terms

Table 1 presents the regression results of equation (1) for February, March and April, and equation (2) for the other 9 months, where the price and excise tax are expressed in nominal terms, for both pre-2010 and post-2010.

The contemporaneous pass-through coefficient is 1.21 (95\% CI 1.18 to 1.25 ) for pre-2010 and 1.11 (95\% CI 1.06 to 1.15 ) for post-2010. Thus, a R1 increase in the excise tax, announced in the latter part of February, was associated, on average, with a R1.21 price increase in March before 2010 and a R1.11 price increase after 2010.

The nominal tax increase is contemporaneously overshifted pre-2010, since the 95\% CI lies above 1.14 (the pass-through coefficient that indicates full pass-through). In the post-2010 period we cannot reject the null hypothesis that the nominal tax

Table 1 Pass-through coefficients (February to April) and monthly effects, nominal prices

\begin{tabular}{|c|c|c|c|c|c|c|c|c|}
\hline \multirow[b]{2}{*}{ Data from month } & \multicolumn{4}{|l|}{ Pre-2010 } & \multicolumn{4}{|l|}{ Post-2010 } \\
\hline & $\beta$ (Feb-Apr) or $\delta$ & $95 \% \mathrm{Cl}$ & $\mathrm{N}$ & $R^{2}$ & $\beta$ & $95 \% \mathrm{Cl}$ & $\mathrm{N}$ & $R^{2}$ \\
\hline Feb & $0.04^{* * *}$ & 0.03 to 0.06 & 1676 & 0.02 & 0.02 & -0.01 to 0.05 & 1213 & 0.00 \\
\hline Apr & $0.13^{* * *}$ & 0.10 to 0.15 & 1176 & 0.09 & $0.12^{* * *}$ & 0.09 to 0.14 & 1678 & 0.06 \\
\hline May & $0.04^{* * *}$ & 0.02 to 0.06 & 1199 & 0.03 & $0.01^{* * *}$ & -0.00 to 0.03 & 1606 & 0.00 \\
\hline Jun & $0.05^{* * *}$ & 0.03 to 0.06 & 1211 & 0.04 & 0.00 & -0.02 to 0.02 & 1602 & 0.00 \\
\hline Aug & $0.94^{* * *}$ & 0.88 to 1.00 & 1210 & 0.54 & $0.15^{* * *}$ & 0.13 to 0.18 & 1493 & 0.14 \\
\hline Sep & $0.11^{* * *}$ & 0.09 to 0.14 & 1202 & 0.09 & $0.17^{* * *}$ & 0.14 to 0.20 & 1436 & 0.11 \\
\hline Oct & $0.05^{* * *}$ & 0.03 to 0.06 & 1205 & 0.03 & 0.01 & -0.01 to 0.02 & 1447 & 0.00 \\
\hline Nov & $0.04^{* * *}$ & 0.02 to 0.05 & 1190 & 0.02 & $0.02^{*}$ & -0.00 to 0.04 & 1447 & 0.00 \\
\hline Dec & 0.02 & -0.01 to 0.05 & 1189 & 0.00 & $0.02^{* *}$ & 0.00 to 0.03 & 1455 & 0.00 \\
\hline Jan & $0.03^{* * *}$ & 0.01 to 0.05 & 1151 & 0.01 & -0.00 & -0.02 to 0.01 & 1280 & 0.00 \\
\hline
\end{tabular}

The $\beta$ coefficients for February to April are derived from equation 1 (in text), and are pass-through coefficients. The $\delta$ coefficients for May to January are derived from equation 2 and indicate the month-on-month average increase in cigarette prices, expressed in rand per pack. $\mathrm{N}=$ the number of brand-region combinations. Significance: ${ }^{* *}=1 \% ;{ }^{*}=5 \% ;{ }^{*}=10 \%$ 
Table 2 Pass-through coefficients (February to April) and monthly effects, real prices

\begin{tabular}{|c|c|c|c|c|c|c|c|c|}
\hline & Pre-2010 & & & & Post-2010 & & & \\
\hline Data from month & $\beta$ (Feb-Apr) or $\delta$ & $95 \% \mathrm{Cl}$ & $\mathrm{N}$ & $\mathrm{R}^{2}$ & $\beta$ & $95 \% \mathrm{Cl}$ & $\mathrm{N}$ & $\mathrm{R}^{2}$ \\
\hline Feb & $-0.12^{\star * *}$ & -0.13 to -0.10 & 1676 & 0.12 & $-0.30 * * *$ & -0.34 to -0.27 & 1213 & 0.19 \\
\hline Mar & $1.06^{* * *}$ & 1.02 to 1.10 & 1700 & 0.77 & $0.75^{* * *}$ & 0.70 to 0.80 & 1187 & 0.44 \\
\hline Apr & $-0.04^{* * *}$ & -0.07 to -0.01 & 1176 & 0.01 & $0.04^{* * *}$ & 0.02 to 0.06 & 1678 & 0.01 \\
\hline May & $-0.04^{* * *}$ & -0.06 to -0.02 & 1199 & 0.02 & $-0.05^{* * *}$ & -0.06 to -0.03 & 1606 & 0.02 \\
\hline Jun & $-0.06^{* * *}$ & -0.08 to -0.04 & 1211 & 0.03 & $-0.07^{* * *}$ & -0.09 to -0.05 & 1602 & 0.03 \\
\hline Jul & $0.14^{* * *}$ & 0.09 to 0.19 & 1216 & 0.05 & $-0.11^{* * *}$ & -0.14 to -0.09 & 1667 & 0.06 \\
\hline Aug & $1.04^{* * *}$ & 0.98 to 1.11 & 1210 & 0.52 & $0.12^{* * *}$ & 0.09 to 0.14 & 1493 & 0.09 \\
\hline Sep & $0.05^{* * *}$ & 0.02 to 0.08 & 1202 & 0.01 & $0.08^{* * *}$ & 0.05 to 0.12 & 1436 & 0.03 \\
\hline Oct & $0.05^{* * *}$ & 0.03 to 0.08 & 1205 & 0.03 & $-0.09 * * *$ & -0.11 to -0.07 & 1447 & 0.08 \\
\hline Nov & $0.04^{* * *}$ & 0.02 to 0.06 & 1190 & 0.02 & $-0.04^{* * *}$ & -0.06 to -0.02 & 1447 & 0.01 \\
\hline Dec & 0.03 & -0.01 to 0.07 & 1189 & 0.00 & $-0.03^{* * *}$ & -0.04 to -0.01 & 1455 & 0.01 \\
\hline Jan & $-0.07^{* * *}$ & -0.09 to 0.04 & 1151 & 0.03 & $-0.13^{* * *}$ & -0.15 to -0.11 & 1280 & 0.16 \\
\hline
\end{tabular}

The $\beta$ coefficients for February to April are derived from equation 1 (in text), and are pass-through coefficients. The $\delta$ coefficients for May to January are derived from equation 2 and indicate the month-on-month average increase in cigarette prices, expressed in rand per pack. $\mathrm{N}=$ the number of brand-region combinations.

Significance: ${ }^{* *}=1 \% ;{ }^{* *}=5 \% ;{ }^{*}=10 \%$

increase is contemporaneously fully passed through, since 1.14 is included in the $95 \% \mathrm{CI}$.

There is practically no evidence that the tobacco industry pre-emptively raises the price of cigarettes in the month before the tax increase, given the small, albeit significant, pass-through coefficient (0.04) for February pre-2010, and the insignificant pass-through coefficient post-2010. There is some evidence for a 1-month delayed pass-through effect, with pass-through coefficients of 0.13 pre-2010 and 0.12 post-2010.

The pass-through in the 'three-month window' is the sum of the pass-through coefficients in February, March and April. This gives an indication of the 'long-term' impact of the excise tax change on the price, although we acknowledge that this 'threemonth window' is rather arbitrary. For pre-2010, the 3-month pass-through is 1.38 (95\% CI 1.34 to 1.42$)$ and for post-2010 it is 1.25 (95\% CI 1.19 to 1.31 ). Thus, the tax increase is overshifted in both periods. However, recalling that the pass-through coefficients based on nominal prices and excise taxes are likely to be biased upwards, this result is treated with caution.

The coefficients for May through January are not pass-through coefficients, but indicate the month-on-month average increase in the nominal price of cigarettes, expressed in rand per pack. For example, the coefficient for May in the pre-2010 period (0.04) indicates that the nominal price of cigarettes increased by an average of R0.04 per pack in May in that period.

With the exception of July, August and September, the monthly nominal price increases were extremely small, in both pre-2010 and post-2010 periods, implying that nominal cigarette prices were largely kept unchanged in those months.

Pre-2010, nominal cigarette prices increased sharply in July (average of R0.33) and August (average of R0.94), which, independent of the tax-induced price increase in March, represents an $8.1 \%$ increase in the average real price (for the 2 months combined) in the 2001-2010 period. Post-2010, the July and August price increases were miniscule in comparison (R0.11 and R0.15).

\section{Analysis in real terms}

Table 2 presents the same regression equation as table 1 , but the analysis is performed in real terms. All nominal prices and taxes, in level terms, were deflated by the monthly all-country CPI to give constant December 2012 prices, from which the first differences were obtained. This model is likely to yield more realistic pass-through coefficients and non-tax-related monthly effects, because it assumes that nominal costs of production increase in line with inflation, rather than staying constant. In this specification, all pass-through coefficients and month effects are smaller than those presented in table 1.

For pre-2010, the contemporaneous pass-through coefficient is 1.06 (95\% CI 1.02 to 1.10$)$, and the long-run pass-through coefficient is 0.90 ( $95 \% \mathrm{CI} 0.85$ to 0.95$)$. For post-2010 the contemporaneous pass-through coefficient is $0.75 \quad(95 \% \mathrm{CI}$ 0.70 to 0.80 ) and the long-run pass-through coefficient is 0.49 (95\% CI 0.42 to 0.56 ). These results strongly suggest that the excise tax increases, expressed in real terms, were undershifted in both periods, but that the tax was increasingly undershifted in the post-2010 period.

The price increases in the other 9 months are specified to not be related to the March tax increase. Four of the 9 months pre-2010 and 7 of the 9 months post- 2010 had negative monthly effects. The nominal prices in those months were generally unchanged, but the real price was eroded by inflation. In the pre-2010 period there was a sizeable real price increase in July (R0.14 in constant December 2012 prices) and August (R1.04). Post-2010 the July real price effect became negative, while the August and September real price effects were modestly positive.

The sum of the 9-monthly coefficients is R1.28 pre-2010 and negative $\mathrm{R} 0.32$ post-2010. Thus, other than the tax-related price changes, there was a substantial (average of $5.7 \%$ per annum) increase in the real price of cigarettes during the course of the year pre-2010, and a modest (average of $1.1 \%$ per annum) decrease in the real price during the course of the year post-2010.

\section{DISCUSSION}

As one of the first middle-income countries to use excise tax increases as a tobacco control tool, South Africa has attracted much attention from the tobacco control community in the past two decades. ${ }^{2} 2829$ The effectiveness of excise tax increases to reduce tobacco consumption depends crucially on how it impacts the retail price. In this paper we used a large data set of cigarette prices, collected by Statistics South Africa, to examine this relationship between 2001 and 2015 .

Before 2010 there were two sizeable retail price increases each year, namely in March and July/August. Expressed in real terms, 
the excise tax was slightly undershifted in March, meaning that the industry bore a small proportion of the tax increase. As a result, the net-of-tax price decreased in March. In July and/or August the tobacco industry substantially increased the retail price of cigarettes, more than compensating for the drop in the net-of-tax price in March.

The combined effect of the tax-induced price increase in March and the discretionary industry-driven price increase in July/August was to substantially raise the real retail price of cigarettes before 2010. In fact, between 1994 and 2010, of all 30 consumer goods and services monitored by Statistics South Africa, cigarettes experienced the largest price increases.

The situation changed dramatically in 2010. Whereas the excise tax was slightly undershifted before 2010, it was substantially undershifted after 2010. Also, whereas discretionary price increases by the tobacco industry raised the real price of cigarettes before 2010, the tobacco industry was unable to do this after 2010. Even though there were modest nominal discretionary price increases after 2010, in real terms they were negative because of the eroding effect of inflation.

One could argue that it is arbitrary to ascribe the February to April price increases to the March tax increase, but the other months' price increases to the tobacco industry's pricing strategy. If one were to take the view that all price increases are related to the excise tax increase, then one would conclude that the excise tax was overshifted before 2010, but was still undershifted in the subsequent period.

The literature on tobacco tax pass-through is limited and is focused primarily on the USA. ${ }^{9-15}$ Most of these studies find that excise taxes are overshifted. Our results are more nuanced. Our preferred results suggest that there is no evidence to indicate that excise taxes are overshifted, although if one takes the view that all price changes can be attributed to the excise tax increase, there was substantial overshifting in the period prior to 2010. Excise taxes are substantially undershifted in the post2010 period.

Pre-2010, the tobacco industry aggressively raised the retail price in July/August, enhancing its turnover and overall profitability, and more than making up for the loss of profit due to the undershifting of the tax increase in March. The very large profits earned by the large tobacco companies, despite a challenging regulatory and legislative environment, attracted a number of aggressive cigarette manufacturers into the market towards the end of the first decade of the 21st century. Some of these manufacturers were legal, some were not. The presence of low-price cigarettes dramatically changed the cigarette market. Previously, the multinational incumbents had been able to exploit their (near-)monopoly power, but this was no longer possible after 2010. It became increasingly difficult to pass excise tax increases onto the consumer. A substantially larger proportion of the tax increase was thus borne by cigarette producers.

From a tobacco control perspective, the developments since 2010 have been unfortunate. Excise tax increases have become less effective in decreasing tobacco consumption, because the excise tax pass-through is lower than before 2010. Furthermore, the competitive environment has changed, with the tobacco industry less able to impose discretionary price increases on its customers. Before 2010, the discretionary price increases made cigarettes less affordable. Since 2010, that support for tobacco control has disappeared.

To achieve the same percentage increase in the retail price, the government has to increase the excise tax by a larger amount than in the past. From a fiscal perspective, that would be beneficial, because a larger increase in the excise tax per cigarette would result in more tax revenues. The government would have to overcome the industry's resistance and its claims that excise tax increases will increase illicit trade. ${ }^{28}$ With sufficient political will, South Africa can revitalise the single most important tool to rejuvenate its flagging tobacco control strategy.

\section{What this paper adds}

- This paper considers the relationship between changes in the excise tax and changes in the retail price in South Africa between 2001 and 2015. Like in many other countries, the cigarette manufacturing industry in South Africa is highly concentrated, giving it much pricing power. Prior to 2010 the industry increased the retail price of cigarettes twice a year: in March in response to the excise tax increase, and in July/ August largely independent of the price.

- The very high net-of-tax prices earned by the incumbent firms attracted competitors to the market, which competed largely on price. The increased levels of competition reduced the power of firms to pass through the tax increases and raise the retail price. Since 2010 the excise tax increases have been undershifted.

- South Africa's experience indicates that tobacco companies' ability to pass through the excise tax is constrained by the degree of competition in the market. This has implications for the effectiveness of excise tax increases as a tobacco control tool.

Contributors DJL performed the statistical analysis and wrote the initial draft. CVW initiated the project and wrote the final draft.

Funding This work was supported by the Bill \& Melinda Gates Foundation grant number 408254 (IRMA 20177).

Competing interests None declared.

Provenance and peer review Not commissioned; externally peer reviewed.

Open Access This is an Open Access article distributed in accordance with the Creative Commons Attribution Non Commercial (CC BY-NC 4.0) license, which permits others to distribute, remix, adapt, build upon this work non-commercially, and license their derivative works on different terms, provided the original work is properly cited and the use is non-commercial. See: http://creativecommons.org/ licenses/by-nc/4.0/

(c) Article author(s) (or their employer(s) unless otherwise stated in the text of the article) 2018. All rights reserved. No commercial use is permitted unless otherwise expressly granted.

\section{REFERENCES}

1 IARC. Effectiveness of Tax and Price Policies for Tobacco Control. Lyon, France: International Agency for Research on Cancer (IARC), 2011.

2 van Walbeek C. The economics of tobacco control in South Africa. Cape Town: University of Cape Town, 2005

3 Malan M, Leaver R. Political change in South Africa: New tobacco control and public health Policies. In: Beyer de J, Brigden W, eds. Tobacco Control Policy: Strategies, Successes \& Setbacks. Washington and Ottawa: World Bank and Research for International Tobacco Control, 2003.

4 Euromonitor. Cigarettes - South Africa. Country Sector Briefing. Euromonitor International, 2007.

5 Euromonitor. Cigarettes in South Africa. Euromonitor International, 2013.

6 Blecher EH, van Walbeek CP. Cigarette affordability trends: an update and some methodological comments. Tob Control 2009;18:167-75.

7 Shisana O, Labadarios D, Rehle T. South african national health and nutrition examination survey (SANHANES-1). Available from: http://www.hsrc.ac.za/en/ research-outputs/view/6493 (2013 17 April 2014).

8 van Walbeek C. The economics of tobacco control (Part 2): evidence from the ITC Project. Tob Control 2015;24:iii1-iii3.

9 Barzel Y. An alternative approach to the analysis of taxation. Journal of Political Economy 1976;84:1177-97.

10 Espinosa J, Evans WN. Excise Taxes, Tax incidence and the flight to quality: Evidence from scanner data. Public Finance Review 2013;41:147-76. 
11 Hanson A, Sullivan R. The incidence of tobacco taxation: Evidence from geographic Micro-Level data. Natl Tax J 2009;62:677-98.

12 Harding M, Leibtag E, Lovenheim MF. The Heterogeneous Geographic and Socioeconomic Incidence of Cigarette Taxes: Evidence from Nielsen Homescan Data. 4. American Economic Journal: Economic Policy, 2012:169-98.

13 Harris J. The 1983 Increase in the Federal Cigarette Excise Tax. National Bureau of Economic Research, 1987:87-112.

14 Keeler TE, Hu TW, Barnett PG, et al. Do cigarette producers price-discriminate by state? An empirical analysis of local cigarette pricing and taxation. $J$ Health Econ 1996;15:499-512.

15 Sullivan RS, Dutkowsky DH. The effect of cigarette taxation on prices: An empirical analysis using Local-Level data. Public Finance Review 2012;40:687-711.

16 Besley T, Rosen H. Sales Taxes and Prices: An Empirical Analysis. National Bureau of Economic Research, 1998.

17 Carbonnier C. Who pays sales taxes? Evidence from French VAT reforms, 1987-1999. J Public Econ 2007:91(5-6):1219-29.

18 Young DJ, Bielińska-Kwapisz A. Alcohol taxes and beverage prices. Natl Tax J 2002;55:57-73

19 Bakó B, Berezvai Z. Excise tax overshifting in the hungarian beer market. 2013. Available from: http://unipub.lib.uni-corvinus.hu/1263/1/tax_overflow.pdf

20 Delipalla S, O'Donnell O. Estimating tax incidence, market power and market conduct: The European cigarette industry. Int J Ind Organ 2001;19:885-908.
21 Viren M. Does the Value-Added Tax Shift to Consumption Prices? AUCO Czech Economic review, 2009:123-42.

22 Bergman UMaH, N.L. Excise Tax Pass-Through on Beverage Prices, 2009.

23 Gilmore AB, Tavakoly B, Taylor G, et al. Understanding tobacco industry pricing strategy and whether it undermines tobacco tax policy: the example of the UK cigarette market. Addiction 2013;108:1317-26.

24 Kenkel DS. Are alcohol tax hikes fully passed through to prices? evidence from alaska. American Economic Review 2005;95:273-7.

25 Russell C, van Walbeek C. How does a change in the excise tax on beer impact beer retail prices in South Africa? South African Journal of Economics 2016.

26 Xu X, Malarcher A, O'Halloran A, et al. Does every US smoker bear the same cigarette tax? Addiction 2014;109:1741-9.

27 WHO. WHO Technical Manual on Tobacco Tax Administration. Geneva: World Health Organization, 2010. Available from. http://apps.who.int/iris/bitstream/10665/44316/ 1/9789241563994_eng.pdf

28 Chaloupka FJ. Curbing the Epidemic: Governments and the Economics of Tobacco Control. Washington, DC: World Bank, 1999.

29 Blecher E. Taxes on tobacco, alcohol and sugar sweetened beverages: Linkages and lessons learned. Soc Sci Med 2015;136-137:175-9.

30 van Walbeek C, Shai L. Are the tobacco industry's claims about the size of the illicit cigarette market credible? The case of South Africa. Tob Control 2015;24(e2):e142-6. 